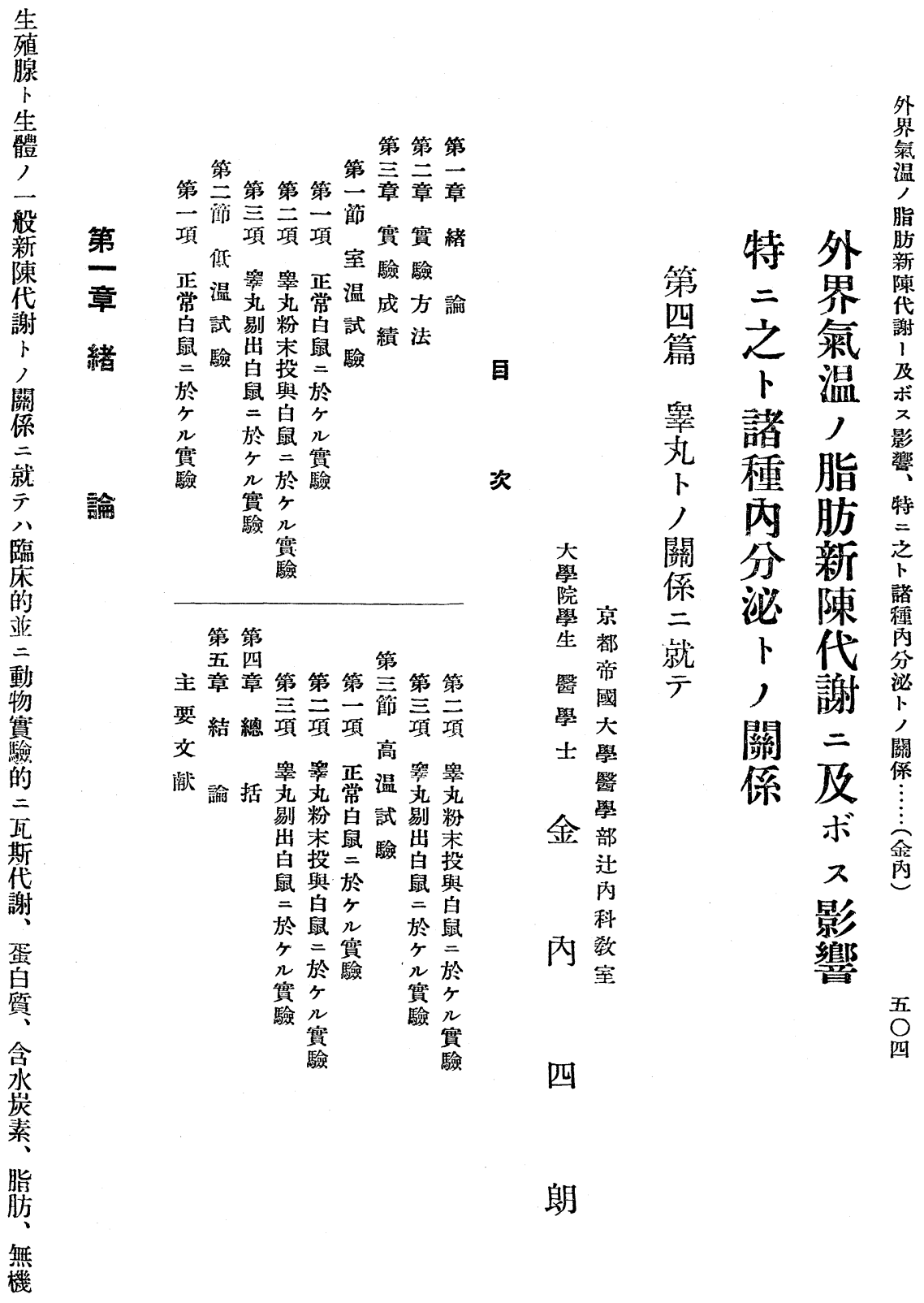




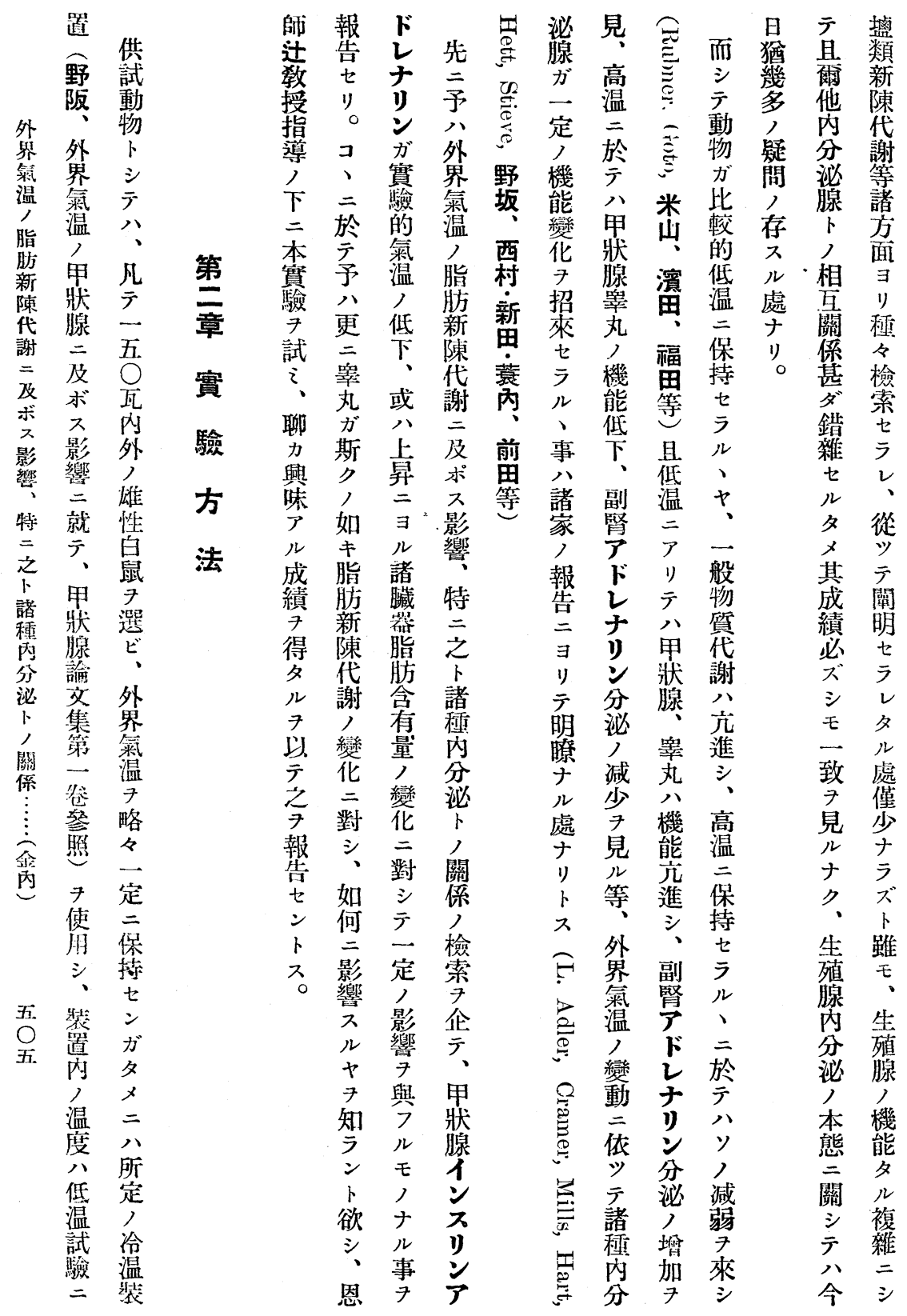




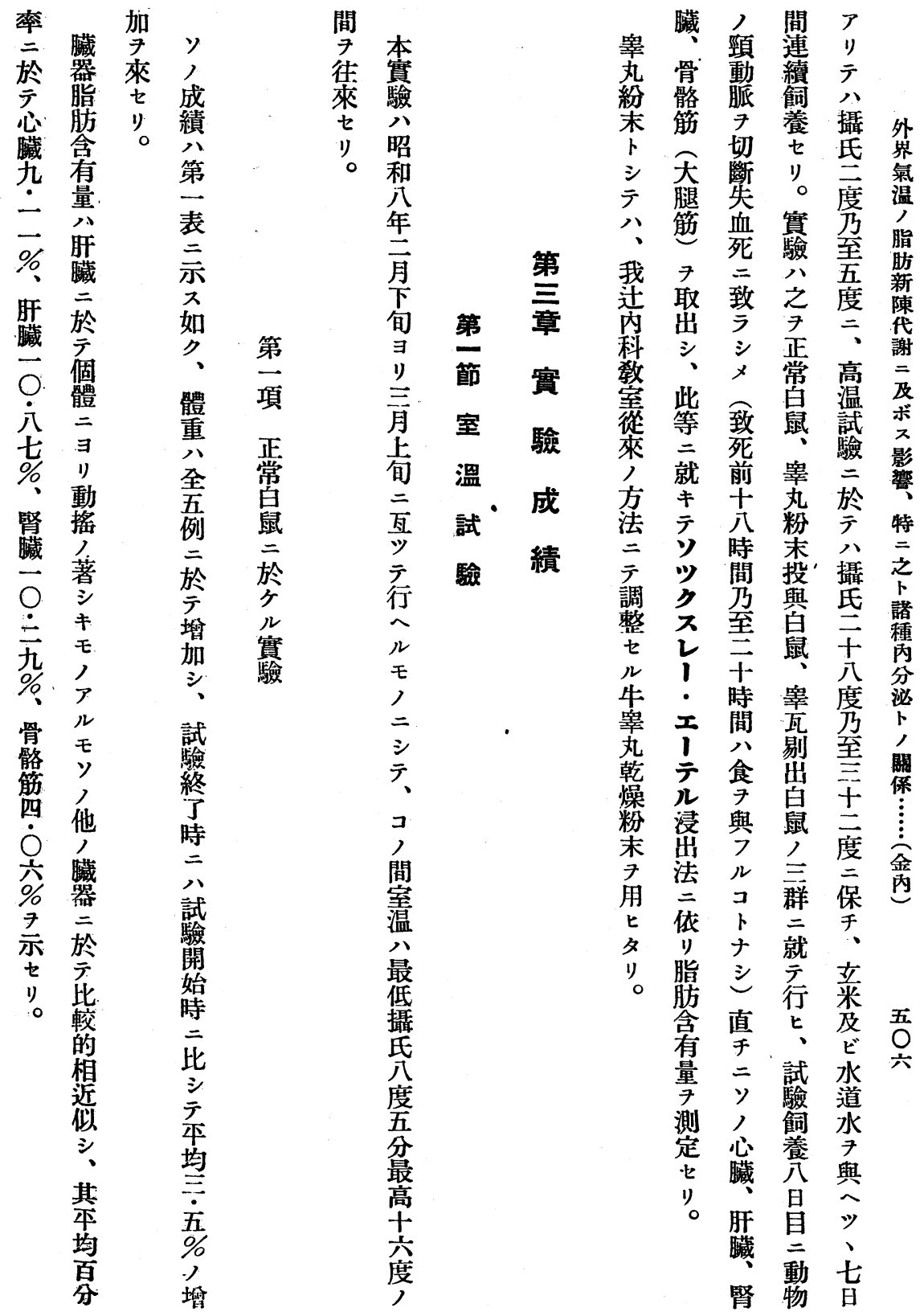




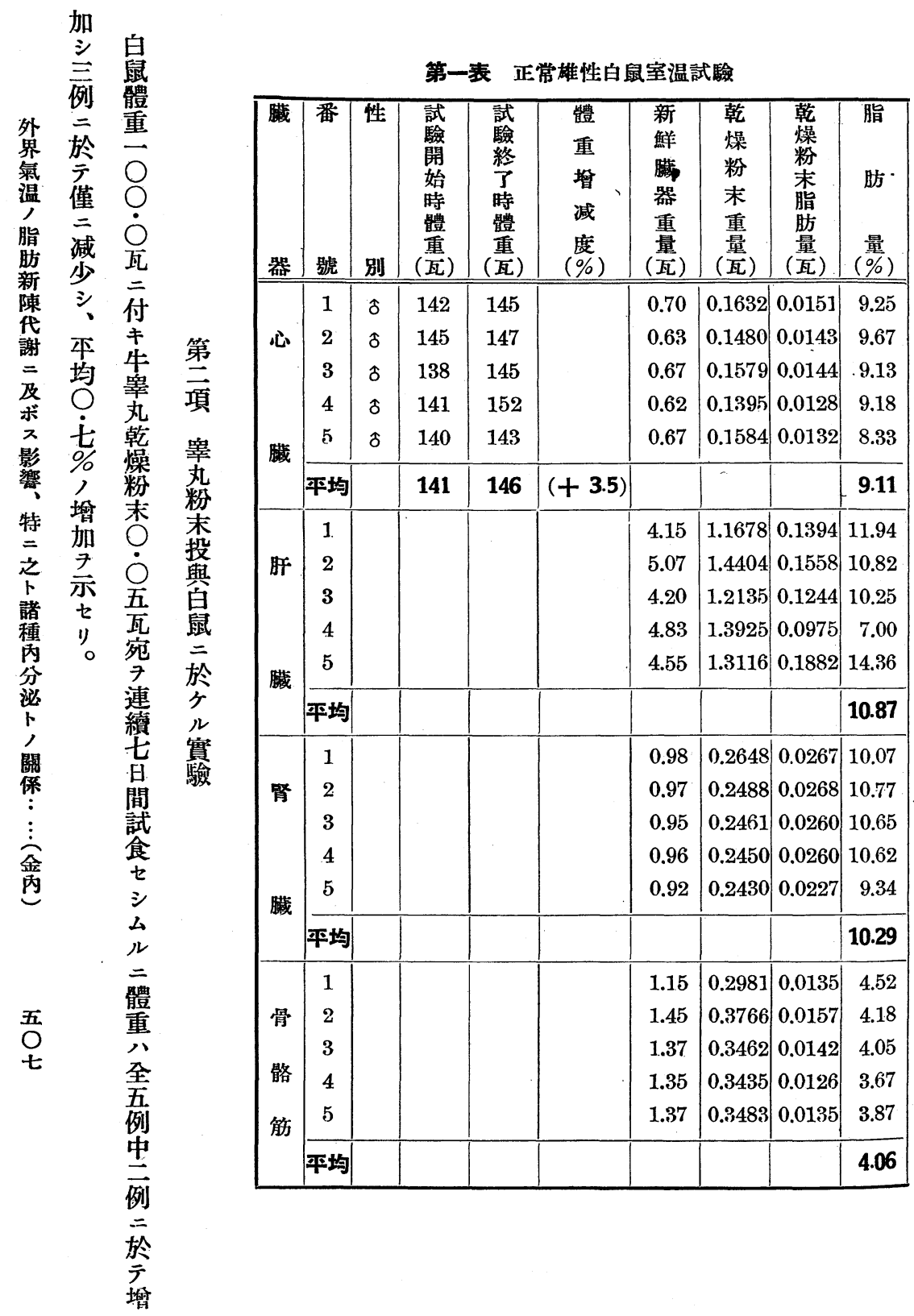


第二表 悬丸粉末投與白鼠室温試驗

\begin{tabular}{|c|c|c|c|c|c|c|c|c|c|}
\hline 器 & 號 & 別 & $\begin{array}{c}\text { 試 } \\
\text { 驗 } \\
\text { 開 } \\
\text { 始 } \\
\text { 時 } \\
\text { 體 } \\
\text { 重 } \\
\text { (桼) } \\
\end{array}$ & $\begin{array}{c}\text { 試 } \\
\text { 驗 } \\
\text { 蔠 } \\
\text { 時 } \\
\text { 體 } \\
\text { 重 } \\
(\text { 酉) }\end{array}$ & $\begin{array}{l}\text { 體 } \\
\text { 重 } \\
\text { 增 } \\
\text { 减 } \\
\text { 度 } \\
(\%) \\
\end{array}$ & $\begin{array}{c}\text { 新 } \\
\text { 鮮 } \\
\text { 臟 } \\
\text { 器 } \\
\text { 重 } \\
\text { 量 } \\
(\text { (瓦) }\end{array}$ & $\begin{array}{c}\text { 乾 } \\
\text { 燥 } \\
\text { 粉 } \\
\text { 末 } \\
\text { 重 } \\
\text { 量 } \\
\text { (桼) }\end{array}$ & $\begin{array}{c}\text { 乾 } \\
\text { 燥 } \\
\text { 粉 } \\
\text { 杰 } \\
\text { 脂 } \\
\text { 肪 } \\
\text { 量 } \\
(\text { 桼 }) \\
\end{array}$ & $\begin{array}{c}\text { 脂 } \\
\text { 肪 } \\
\text { 量 } \\
(\%) \\
\end{array}$ \\
\hline \multirow{4}{*}{ ic } & 1 & $\hat{o}$ & 152 & 150 & & 0.57 & 0.1358 & 0.0104 & 7.66 \\
\hline & 3 & $\hat{\delta}$ & 162 & 168 & & 0.65 & 0.1545 & 0.0134 & 8.67 \\
\hline & 3 & $\hat{\delta}$ & 166 & 175 & & 0.70 & 0.1629 & 0.0132 & 8.10 \\
\hline & 4 & $\hat{\delta}$ & 146 & 145 & & 0.75 & 0.1723 & 0.0129 & 7.52 \\
\hline \multirow{2}{*}{ 臟 } & 5 & $\hat{\delta}$ & 132 & 127 & & $0.6 \theta$ & 0.1457 & 0.0123 & 8.44 \\
\hline & 平均 & & 152 & 153 & $(+0.7)$ & & & & 8.08 \\
\hline \multirow{4}{*}{ 䏦 } & 1 & & & & & 5.45 & 1.6313 & 0.1477 & 9.06 \\
\hline & 2 & & & & & 6.30 & 1.9084 & 0.1899 & 9.97 \\
\hline & 3 & & & & & 4.78 & 1.3955 & 0.1381 & 9.90 \\
\hline & 4 & & & & & 5.45 & 1.5590 & 0.1550 & 9.95 \\
\hline \multirow{2}{*}{ 臟 } & 5 & & & & & 4.30 & 1.2499 & 0.1043 & 8.35 \\
\hline & 平均 & & & & & & & & 9.45 \\
\hline & 1 & & & & & 1.08 & 0.2716 & 0.0285 & 10.52 \\
\hline & 2 & & & & & 1.05 & 0.2727 & 0.0296 & 10.85 \\
\hline & 3 & & & & & 1.02 & 0.2600 & 0.0274 & 10.53 \\
\hline & 4 & & & & & 1.32 & 0.3070 & 0.0333 & 10.85 \\
\hline & 5 & & & & & 0.88 & 0.2166 & 0.0215 & 9.92 \\
\hline 臟 & 平均 & & & & & & & & 10.54 \\
\hline \multirow{6}{*}{ 筋 } & 1. & & & & & 1.48 & 0.3619 & 0.0102 & 2.82 \\
\hline & 2 & & & & & 1.65 & 0.4148 & 0.0184 & 4.43 \\
\hline & 3 & & & & & 1.52 & 0.3727 & 0.0126 & 3.39 \\
\hline & 4 & & & & & 1.67 & 0.3918 & 0.0125 & 3.19 \\
\hline & 5 & & & & & 1.55 & 0.3838 & 0.0128 & 3.34 \\
\hline & 平均 & & & & & & & & 3.43 \\
\hline
\end{tabular}

明 $\%$ 藏

减腎脂

少 臟 肪

七 一 含 外

ル 有 界

7 五 量 氣

知五 四 温

可 \% 見 脂

可\%、ル得

方骨二、新

第 筴 何 倲

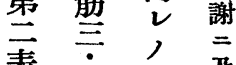

表罳藏藏

照

$\%$ 三 影

二 於 䬤

シ

テ モ 特

之觶之

$7=$

前 $三$

種

項 ル合

正動 分

常 搖 泌

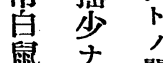

鼠ナ關

群 ク、保

較

レ,

算均尔

臟 百

于 分

除 率

キ心

他 臟

त

익

テ

\% $\%$

獩 訮

器 臟

於 九

亏 四

著五 
第三表 睪丸剔出白鼠室温試驗

\begin{tabular}{|c|c|c|c|c|c|c|c|c|c|}
\hline 藏蔵 & 番 & 性 & $\begin{array}{c}\text { 試 } \\
\text { 驗 } \\
\text { 㼙 } \\
\text { 喑 } \\
\text { 體 } \\
\text { 重 } \\
\text { (瓦) }\end{array}$ & $\begin{array}{c}\text { 試 } \\
\text { 驗 } \\
\text { 終 } \\
\text { 了 } \\
\text { 時 } \\
\text { 體 } \\
\text { (重) } \\
\end{array}$ & $\begin{array}{l}\text { 體 } \\
\text { 重 } \\
\text { 管 } \\
\text { 减 } \\
(\%) \\
(\%)\end{array}$ & $\begin{array}{l}\text { 新 } \\
\text { 鲜 } \\
\text { 欌 } \\
\text { 器 } \\
\text { 重 } \\
\text { 量 } \\
\text { (瓦) }\end{array}$ & 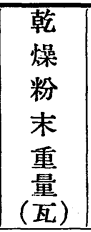 & 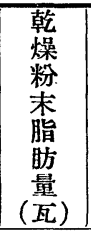 & $\begin{array}{l}\text { 脂 } \\
\text { 肪 } \\
\left(\frac{9}{\%}\right) \\
(\%)\end{array}$ \\
\hline \multirow{4}{*}{ 心 } & 1 & $\hat{o}$ & 145 & 145 & & 0.60 & $|0.1318|$ & $|0.0126|$ & 9.56 \\
\hline & 2 & $\hat{o}$ & 133 & 135 & & 0.68 & 0.1560 & 0.0141 & 9.04 \\
\hline & 3 & $\delta$ & 145 & 155 & & 0.68 & 0.1478 & 0.0140 & 9.46 \\
\hline & 4 & $\hat{\delta}$ & 135 & 138 & & 0.58 & 0.1363 & 0.0122 & 8.95 \\
\hline \multirow{2}{*}{ 㵴 } & 5 & $\delta$ & 132 & 142 & & 0.53 & 0.1338 & $|0.0102|$ & 7.63 \\
\hline & 平均 & & 138 & 143 & $(+3.6)$ & & & & 8.93 \\
\hline \multirow{4}{*}{ 肝 } & 1 & & & & & 4.87 & 1.3541 & 0.0999 & 7.38 \\
\hline & 2 & & & & & 4.40 & 1.2454 & 0.0894 & 7.17 \\
\hline & 3 & & & & & 4.40 & 1.1989 & $0.0991 \mid$ & 8.26 \\
\hline & 4 & & & & & 3.70 & $|1.0867|$ & 0.0753 & 6.94 \\
\hline \multirow{2}{*}{ 欌 } & 5 & & & & & 4.65 & 1.3694 & 0.0809 & 5.92 \\
\hline & 平均 & & & & & & & & 7.12 \\
\hline \multirow{4}{*}{ 腎 } & 1 & & & & & 1.03 & 0.2616 & {$[0.0267 \mid$} & 10.21 \\
\hline & 2 & & & & & 0.90 & 0.2311 & 0.0284 & 1.2 .29 \\
\hline & 3 & & & & & $1.00^{\circ}$ & 0.2411 & 0.0267 & 11.07 \\
\hline & 4 & & & & & 0.88 & $0.2162 \mid$ & 0.0236 & 10.92 \\
\hline \multirow{2}{*}{ 臟 } & 5 & & & & & 0.86 & 0.1948 & 0.0191 & 9.81 \\
\hline & 平均 & & & & & & & & 10.86 \\
\hline \multirow{6}{*}{$\begin{array}{l}\text { 骨 } \\
\text { 骼 } \\
\text { 筋 }\end{array}$} & 1 & & & & & 1.25 & $0.3045 \mid$ & 0.0085 & 2.79 \\
\hline & 2 & & & & & 1.08 & 0.2646 & 0.0091 & 3.44 \\
\hline & 3 & & & & & 1.38 & 0.3259 & 0.0096 & 2.95 \\
\hline & 4 & & & & & 1.50 & 0.3710 & 0.0109 & 2.95 \\
\hline & 5 & & & & & 1.20 & 0.3005 & 0.0080 & 2.66 \\
\hline & 平均 & & & & & & & & 2.96 \\
\hline
\end{tabular}

目 二 第

蔓 恶

7

開 䓿

始 丸

七剔

出

二 泉

體 二

重。於

八而

全告

例喓

中

四

例

三

於

增

加

シ

例

$=$

於

$\bar{\tau}$

粗

广

n

本 
照

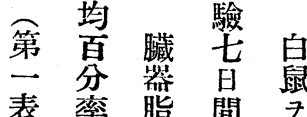

表率脂 間 キ

較心含通 氏

人八量 宁度

ハ立少尔

各 声臟 0 五

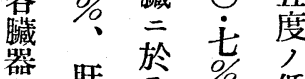

共栞 等\% 任

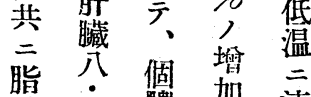

肪分體 加 連

含 九

量、减婜動方間

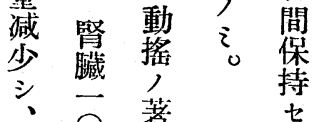

其

度分毛

訮 $\%$

歲骨 ル

骨䇨等

骼 琞 ソ

筋 $\div$ 他

三 三 他

於 差

最二器

モ シ 二

著厅、於

ナ之八

ル 斯

于 正 力

知常 ル

儿白 事

○鼠 ナ

第室り、

四試

表羷尔

四

例

於

$\bar{\gamma}$

减

少

例

$=$

於

亏

塯

加

シ $\begin{array}{ll}\text { 五 } & \\ \text { 分 } \\ \text { 示 } \\ \text { 試 }\end{array}$

シ 心

試 和

薟 八

装算

过

氣页

第 温

而分 り 節

項 最 豆

正常乴 卢

但

温

試

鼠度 於

於最行

泉高比

寍度 ル

7 モ

標ノ

小 =

リ テ

コ

間

試

室

最

低

攝

式

度

五

分

最

高

宍

度

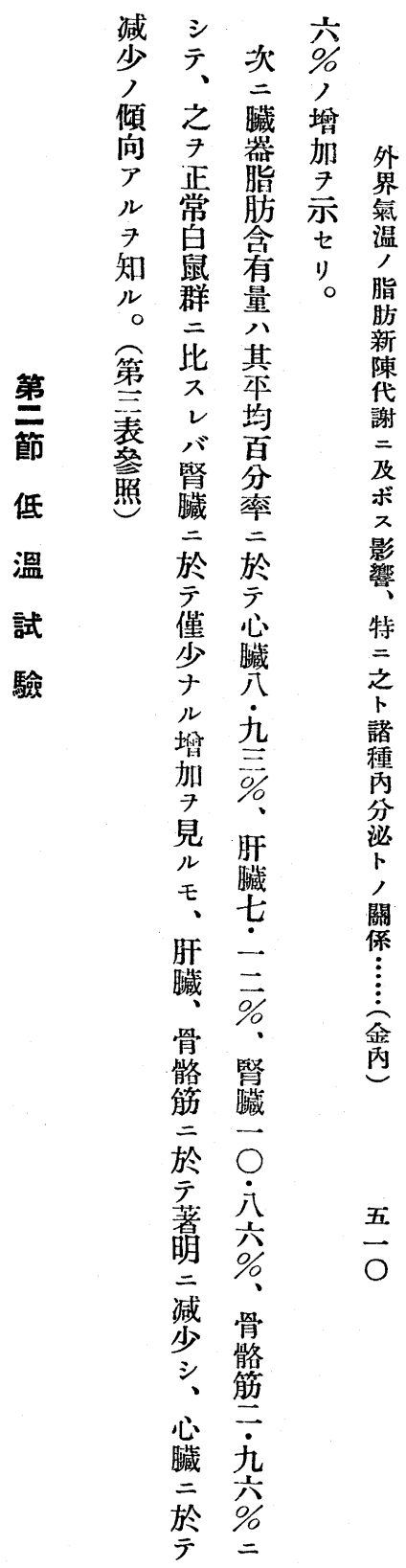

傾之臟 霄

向 7 器 加外

ル 正常脂 示 界

フ白含 七温

知鼠有り。脂

○样量肪

第 本化

謝

ボ

影

特

之

諸

内

泌

關

係 


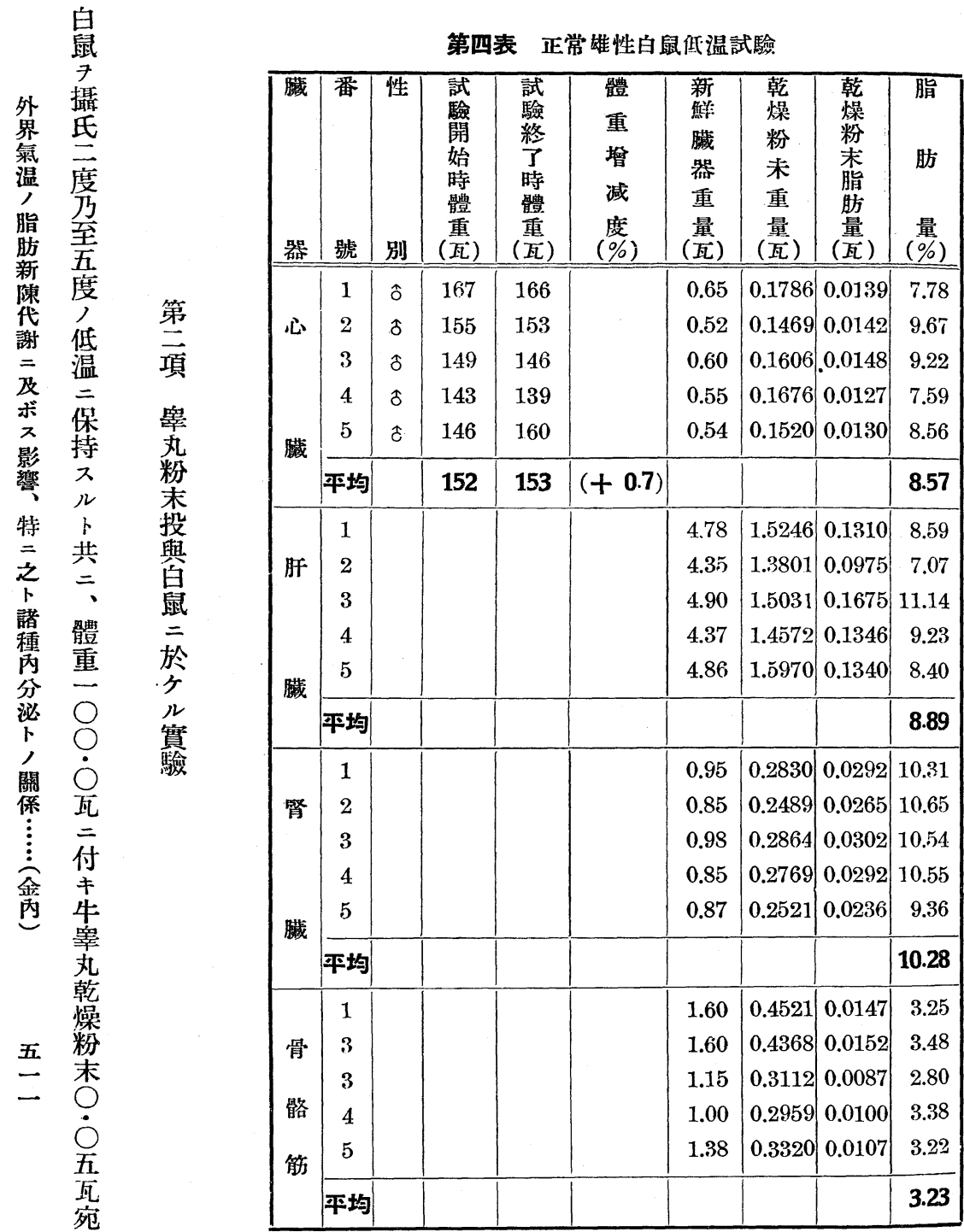


第五表 睪丸粉末投與白鼠低温試驗

\begin{tabular}{|c|c|c|c|c|c|c|c|c|c|}
\hline 器 & 番 & 別 & $\begin{array}{c}\text { 試 } \\
\text { 驗 } \\
\text { 開 } \\
\text { 始 } \\
\text { 啫 } \\
\text { 體 } \\
\text { (重) } \\
\end{array}$ & $\begin{array}{c}\text { 試 } \\
\text { 驗 } \\
\text { 終 } \\
\text { 了 } \\
\text { 時 } \\
\text { 體. } \\
\text { 重 } \\
\text { (瓦) }\end{array}$ & $\begin{array}{c}\text { 體 } \\
\text { 重 } \\
\text { 垍 } \\
\text { 减 } \\
\text { 度 } \\
(\%)\end{array}$ & $\begin{array}{l}\text { 新 } \\
\text { 磁 } \\
\text { 臟 } \\
\text { 器 } \\
\text { 重 } \\
\text { 量 } \\
\text { (望) }\end{array}$ & \begin{tabular}{c|} 
乾 \\
燥 \\
粉 \\
末 \\
重 \\
量 \\
(瓦) \\
\end{tabular} & 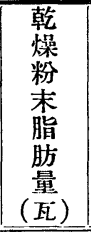 & $\begin{array}{l}\text { 脂 } \\
\text { 肪 } \\
\text { 量 } \\
(\%) \\
\end{array}$ \\
\hline \multirow{4}{*}{ 心 } & 1 & $\hat{o}$ & 172 & 166 & & 0.58 & 0.1460 & $|0.0121|$ & 8.28 \\
\hline & 2 & $\hat{o}$ & 147 & 153 & & 0.72 & $\mid 0.1754$ & 0.0148 & 8.44 \\
\hline & 3 & $\hat{o}$ & 158 & 152 & & 0.70 & 0.1735 & 0.0151 & 8.70 \\
\hline & 4 & $\hat{\delta}$ & 160 & 150 & & 0.62 & 0.1490 & 0.0115 & 7.72 \\
\hline 臟 & 5 & $\hat{\delta}$ & 126 & 115 & & 0.63 & 0.1528 & 0.0127 & 8.31 \\
\hline & 平均 & & 153 & 147 & $(-3.9)$ & & & & 8.29 \\
\hline & 1 & & & & & 5.27 & 1.6167 & 0.1485 & 9.19 \\
\hline \multirow{3}{*}{ 腈 } & 2 & & & & & 4.80 & 1.4226 & 0.1134 & 7.97 \\
\hline & 3 & & & & & 4.95 & 1.4420 & $0.1401 \mid$ & 9.72 \\
\hline & 4 & & & & & 5.10 & 1.5913 & 0.1768 & 11.11 \\
\hline \multirow[t]{2}{*}{ 贜 } & 5 & & & & & 4.25 & 1.2412 & 0.0890 & 7.18 \\
\hline & 平均 & & & & & & & & 9.03 \\
\hline \multirow{6}{*}{ 臓 } & 1 & & & & & 1.12 & 0.3060 & 0.0279 & 9.12 \\
\hline & 2 & & & & & 0.98 & 0.2633 & 0.0261 & 9.93 \\
\hline & 3 & & & & & 1.07 & 0.2876 & 0.0299 & 10.39 \\
\hline & 4 & & & & & 0.90 & 0.2479 & 0.0256 & 10.32 \\
\hline & 5 & & & & & 0.87 & 0.2322 & 0.0202 & 8.70 \\
\hline & 平均 & & & & & & & & 9.69 \\
\hline \multirow{6}{*}{ 骨 } & 1 & & & & & 1.60 & $\mid 0.4196$ & 0.0109 & 2.61 \\
\hline & 2 & & & & & 1.35 & 0.3555 & 0.0113 & 3.18 \\
\hline & 3 & & & & & 1.40 & 0.3539 & 0.0147 & 4.16 \\
\hline & 4 & & & & & 1.42 & $|0.3744|$ & 0.0133 & 3.56 \\
\hline & 5 & & & & & 0.90 & 0.2295 & 0.0069 & 3.01 \\
\hline & 平均 & & & & & & & & 3.30 \\
\hline
\end{tabular}

而减間

方少食

贜 見 三 外

器ルム器

脂○ル妞

肪二温

含管體 脂

有重䐵

量 尘 新

全陳

五 代

本 例

均 中

百四要

分例 $x$

率 = 影

二 於 鹤

於六特

テ 减

心 - - 楛

贜例 諸

八 $=$ 丙

言 於

杂然

$\%$ 霄

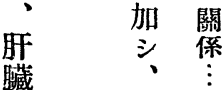

九 試

$\dot{0}$ 䌞

蔠

第 カ カ 腎テク殆骨 ス四温 $\%$

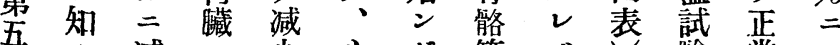

表儿减二少心ト筋バ羷常

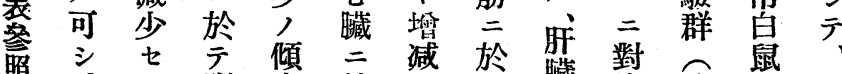

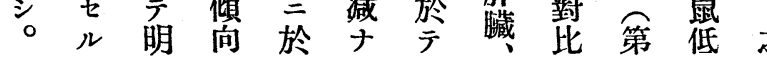


第六表 票丸剔出白鼠低温試驗

\begin{tabular}{|c|c|c|c|c|c|c|c|c|c|}
\hline 臟 & 番 & 別 & $\begin{array}{c}\text { 試 } \\
\text { 驗 } \\
\text { 開 } \\
\text { 始 } \\
\text { 時 } \\
\text { 體 } \\
\text { 重 } \\
\text { (瓦) }\end{array}$ & 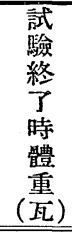 & $\begin{array}{c}\text { 體 } \\
\text { 重 } \\
\text { 燳 } \\
\text { 减 } \\
\text { 度 } \\
(\%) \\
\end{array}$ & $\begin{array}{l}\text { 新 } \\
\text { 焦 } \\
\text { 臟 } \\
\text { 器 } \\
\text { 重 } \\
\text { 量 } \\
\text { (瓦) }\end{array}$ & \begin{tabular}{|c|} 
榦 \\
燥 \\
粉 \\
末 \\
重 \\
量 \\
(瓦) \\
\end{tabular} & \begin{tabular}{|c|} 
榦 \\
燥 \\
粉 \\
㴯 \\
放 \\
(量) \\
\end{tabular} & $\begin{array}{c}\text { 脂 } \\
\text { 肪 } \\
\\
\text { 量 } \\
(\%) \\
\end{array}$ \\
\hline \multirow{4}{*}{ 心 } & 1 & $\hat{\delta}$ & 160 & 164 & & 0.83 & 0.2140 & 0.0179 & 8.39 \\
\hline & 2 & $\hat{\delta}$ & 160 & 163 & & 0.70 & 0.1903 & 0.0184 & 9.67 \\
\hline & 3 & $\hat{o}$ & 161 & 160 & & 0.53 & 0.1492 & 0.0137 & 9.17 \\
\hline & 4 & $\hat{o}$ & 176 & 172 & & 0.78 & 0.1893 & 0.0119 & 6.30 \\
\hline \multirow{2}{*}{ 臟 } & 5 & $\hat{\delta}$ & 162 & 158 & & 0.70 & 0.1674 & 0.0142 & 8.50 \\
\hline & |平均 & & 164 & 153 & $(-0.6)$ & & & & 8.41 \\
\hline \multirow{4}{*}{ 䏦 } & 1 & & & & & 5.48 & 1.4985 & 0.1224 & 8.17 \\
\hline & 2 & & & & & 5.38 & 1.5857 & 0.1821 & 11.49 \\
\hline & 3 & & & & & 4.13 & 1.3248 & 0.1252 & 9.46 \\
\hline & 4 & & & & & 5.15 & 1.4444 & 0.1521 & 10.53 \\
\hline \multirow{2}{*}{ 臟 } & 5 & & & & & 5.25 & 1.5373 & 0.1172 & \begin{tabular}{|l|} 
\\
\end{tabular} \\
\hline & 平均 & & & & & & & & 9.46 \\
\hline \multirow{4}{*}{ 腎 } & 1 & & & & & 1.08 & 0.2798 & 0.0266 & \begin{tabular}{|l|l} 
& 9.51
\end{tabular} \\
\hline & 2 & & & & & 0.98 & 0.2758 & 0.0316 & 11.45 \\
\hline & 3 & & & & & 0.85 & 0.2565 & 0.0295 & 11.50 \\
\hline & 4 & & & & & 1.05 & 0.2769 & 0.0273 & 9.86 \\
\hline \multirow{2}{*}{ 臟 } & 5 & & & & & 1.03 & 0.2743 & 0.0283 & 10.31 \\
\hline & 平均 & & & & & & & & 10.53 \\
\hline \multirow{6}{*}{$\begin{array}{l}\text { 骨 } \\
\text { 骼 } \\
\text { 筋 }\end{array}$} & 1 & & & & & 1.53 & 0.4097 & 0.0127 & 3.10 \\
\hline & 2 & & & & & 1.35 & 0.3804 & 0.0142 & \begin{tabular}{|l|l}
3.73 \\
\end{tabular} \\
\hline & 3 & & & & & 1.65 & 0.4506 & 0.0145 & 3.22 \\
\hline & 4 & & & & & 1.45 & 0.3827 & 0.0087 & 2.27 \\
\hline & 5 & & & & & 1.40 & 0.3733 & 0.0114 & 3.06 \\
\hline & 平均 & & & & & & & & 3.08 \\
\hline
\end{tabular}

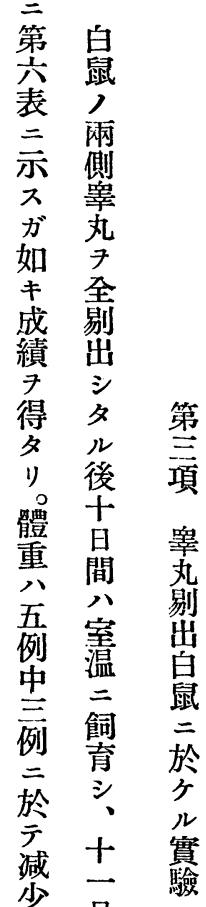




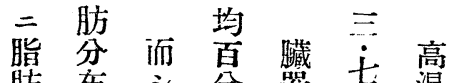

肪市 シ 分器 $\%$ 温

含㳊テ、率脂, 蚂

有長、、肪塯二

量八コ心含塯

季、贜有驾少

心 節 云九量 座テ

臟分得分公來少

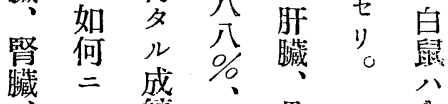

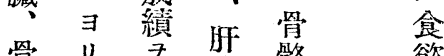

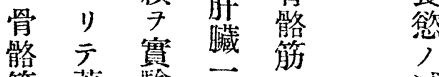

筋 著驗

於只主示

$\bar{\sigma}$ 異 巽 $\overline{0}$ 個

霄于 $\%$ 體

加ルス、

シモル腎

肝ノ前臟動

臟 ル 正 $\rightarrow$ 揫

$=$ 常 $\dot{0}$ 著

於以白杂

辰鼠杂市

僅 ナ 室 \%、7

减。酯骨見

减。試盈婴

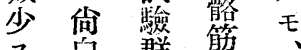

ス白群熊、

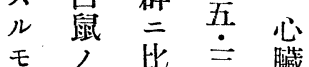

モ 高䘡 三臟

ナ温 ス $\%$ 腎

ル ル 7 贜

事 保 八示 =

八持 不 入 於

㐮七可。等

予步

再蓋琣

再蓋剚

實 體 動

證重 物

七 㙫 體

几 加 内

處占了

于 共脂
度

間 責

7 襝

往 八

來 ス

シ

高 昭

温 和

装

管 兵

第, 月

减項蓆旬

退

入正最り

ル常低 中

二白 攝 旬

力鼠氐二

、 二

八於卉兴

亏 少分

ズル度行

蒀思

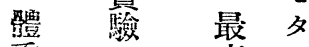

重

全

全

例

中

四

例

=

於

$\bar{T}$

愈

架

高ル

王

度 三

示

t

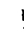

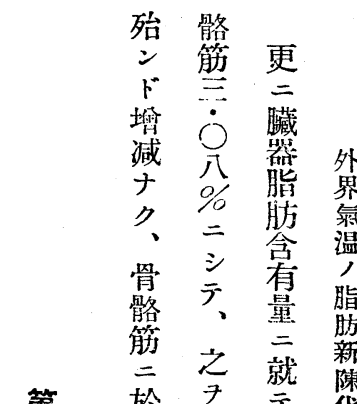

第於焉采倈

節 减常 見

高少泉う采

傾泜侐尔

溫向温平影

試見噞百特

驗分 群

驗分㐿率并

四立諧

表等垂

分

校 心泌

㿥,

バ酉 虜

栞 $\overrightarrow{\%}$

於橗苪

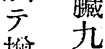

加 四

7 六

見\% 五

モ堅 四

、臓

心 -

臟 $\bigcirc$

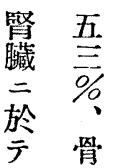




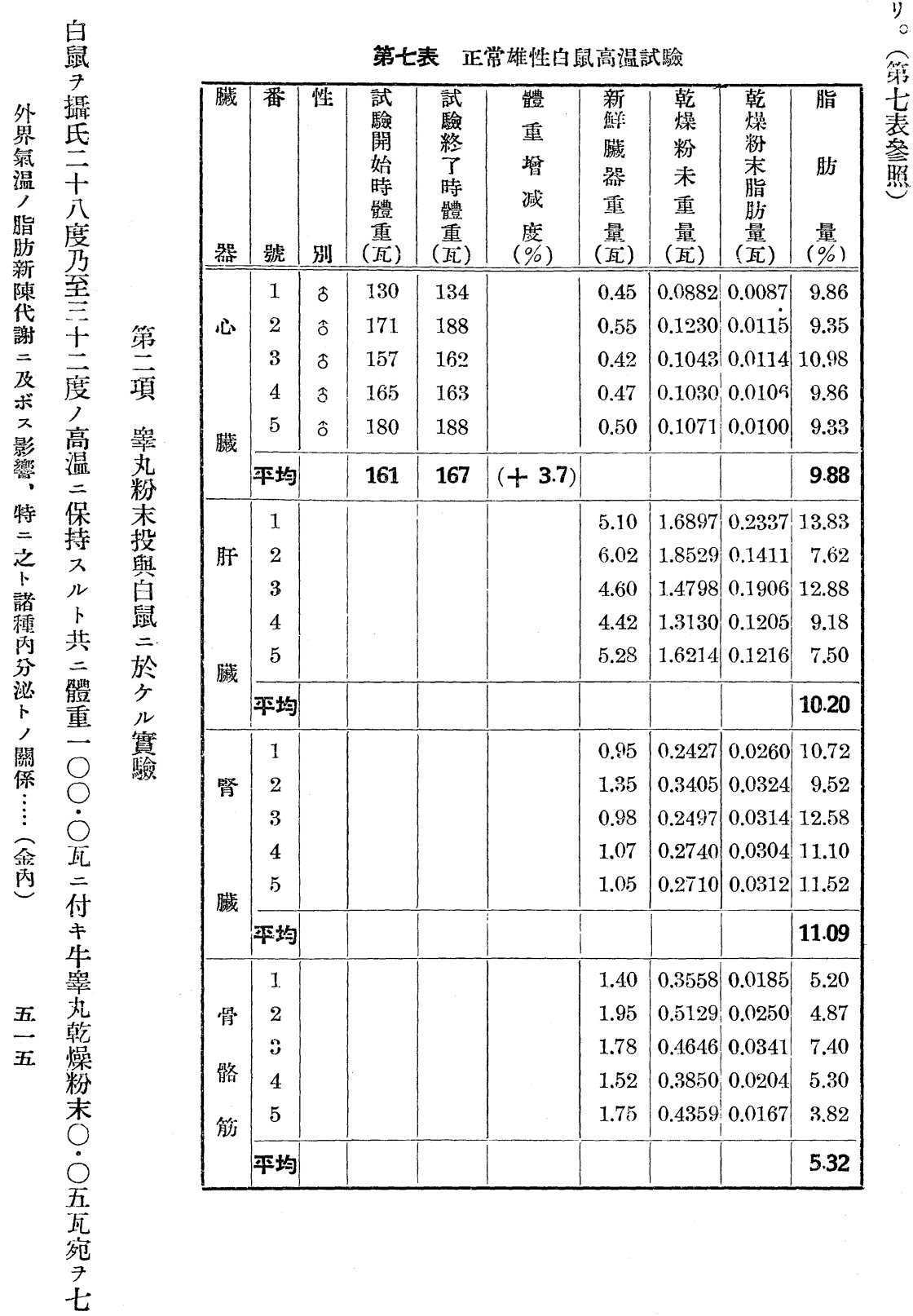


第八表 睪丸粉末投與白鼠高温試驗

\begin{tabular}{|c|c|c|c|c|c|c|c|c|c|}
\hline 臟 & 番 & 性 & $\begin{array}{c}\text { 試 } \\
\text { 驗 } \\
\text { 睤 } \\
\text { 晊 } \\
\text { 體 } \\
\text { 重 } \\
\text { (望) } \\
\end{array}$ & $\begin{array}{c}\text { 試 } \\
\text { 驗 } \\
\text { 終 } \\
\text { 了 } \\
\text { 時 } \\
\text { 體 } \\
\text { 重 } \\
\text { (瓦) }\end{array}$ & $\begin{array}{l}\text { 體 } \\
\text { 重 } \\
\text { 增 } \\
\text { 减 } \\
(\%) \\
(\%) \\
\end{array}$ & 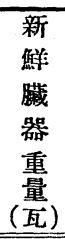 & \begin{tabular}{|c|} 
乾 \\
燥 \\
粉 \\
末 \\
重 \\
(量 \\
$(\kappa)$ \\
\end{tabular} & 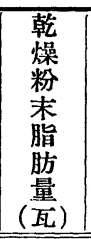 & $\begin{array}{c}\text { 脂 } \\
\text { 肪 } \\
\text { 量 } \\
(\%) \\
\end{array}$ \\
\hline \multirow[b]{5}{*}{ 月 } & 1 & $\hat{\delta}$ & 157 & 173 & & 0.48 & 0.1070 & $0.0121 \mid$ & 11.31 \\
\hline & 2 & $\delta$ & 141 & 150 & & 0.39 & 0.0832 & 0.0087 & 10.47 \\
\hline & 3 & $\hat{\delta}$ & 135 & 144 & & 0.35 & 0.0864 & 0.0084 & $\dot{9} .73$ \\
\hline & 4 & $\hat{o}$ & 135 & 128 & & 0.38 & 0.0731 & 0.0065 & 8.90 \\
\hline & 5 & $\delta$ & 142 & 148 & & 0.41 & $|0.0862|$ & 0.0071 & 8.24 \\
\hline 臓 & 平均 & & 142 & 149 & $(+4.9)$ & & & & 9.73 \\
\hline \multirow{6}{*}{ 肝 } & 1 & & & & & 5.02 & 1.5593 & 0.1292 & 8.29 \\
\hline & 2 & & & & & 5.52 & $|1.6677|$ & 0.1105 & 6.63 \\
\hline & 3 & & & & & 4.98 & 1.4990 & 0.1602 & 10.69 \\
\hline & 4 & & & & & 4.22 & 1.3129 & 0.1126 & 8.58 \\
\hline & 5 & & & & & 4.94 & 1.4871 & 0.1280 & 8.61 \\
\hline & 平均 & & & & & & & & 8.56 \\
\hline \multirow{6}{*}{ 臟 } & 1 & & & & & 0.98 & $|0.2659|$ & 0.0294 & 11.05 \\
\hline & 2 & & & & & 0.80 & 0.2007 & 0.0264 & 13.15 \\
\hline & 3 & & & & & 0.81 & 0.1990 & 0.0231 & 11.62 \\
\hline & 4 & & & & & 0.78 & 0.1848 & 0.0232 & 12.55 \\
\hline & 5 & & & & & 0.82 & 0.2012 & 0.0244 & 12.13 \\
\hline & 平均 & & & & & & & & 12.10 \\
\hline \multirow{6}{*}{$\begin{array}{l}\text { 骨 } \\
\text { 骼 } \\
\text { 筋 }\end{array}$} & 1 & & & & & 1.65 & $|0.4348|$ & $\mid 0.0212$ & 4.88 \\
\hline & 2 & & & & & 1.50 & 0.3762 & 0.0159 & 4.25 \\
\hline & 3 & & & & & 1.32 & 0.3381 & 0.0164 & 4.85 \\
\hline & 4 & & & & & 1.25 & 0.3213 & 0.0147 & $4 . \tilde{5} 8$ \\
\hline & 5 & & & & & 1.80 & 0.4613 & 0.0212 & 4.59 \\
\hline & 平均 & & & & & & & & 4.63 \\
\hline
\end{tabular}

ク、轉 間 平 均 連 百 臟 試 外 分器 食 界 率 脂 $七$ 氣 八肪 三 温 心含 $厶$ 脂 臟有ル脂 九量二㭗 吉見體陳 五見體代 : $=$ 垔 旰全令 臟臓五 八 些例影 五市 中㫈 六 テ 例 特 $\%$ 個 $=$ 、體於之 腎 = 点硣

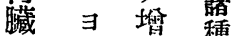
二 二動 三 分 二 播、淡 \% 著例 $\%$ 者 骨手於 保

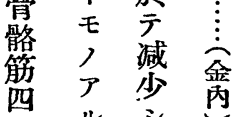
兵 ル 忩 飞本 \% 其 均 二他四

洸, 五 テ、贜 杂 之径塯 正於㚙 正 テ 八减二肝二霄二二羷常公來 表少於臓於减於較群白斯來

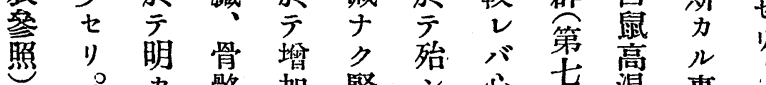

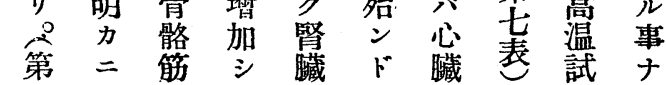


第九表 睪丸剔出白鼠高温試驗

\begin{tabular}{|c|c|c|c|c|c|c|c|c|c|}
\hline 器 & 番 & 別 & $\begin{array}{c}\text { 試 } \\
\text { 驗 } \\
\text { 開 } \\
\text { 始 } \\
\text { 時 } \\
\text { 體 } \\
\text { 重 } \\
(\text { 酉) } \\
\end{array}$ & $\begin{array}{c}\text { 試 } \\
\text { 驗 } \\
\text { 終 } \\
\text { 了 } \\
\text { 時 } \\
\text { 體 } \\
\text { 重 } \\
(\text { (瓦) } \\
\end{array}$ & $\begin{array}{l}\text { 體 } \\
\text { 重 } \\
\text { 增 } \\
\text { 减 } \\
\text { 度 } \\
(\%) \\
\end{array}$ & $\begin{array}{l}\text { 新 } \\
\text { 蘚: } \\
\text { 臟 } \\
\text { 器 } \\
\text { 重 } \\
\text { 量 } \\
(\text { 酉) } \\
\end{array}$ & $\begin{array}{c}\text { 乾 } \\
\text { 燥 } \\
\text { 粉 } \\
\text { 末 } \\
\text { 重 } \\
\text { 量 } \\
(\text { 桼 }) \\
\end{array}$ & \begin{tabular}{|c|} 
乾 \\
燥 \\
粉 \\
杰 \\
脂 \\
肪 \\
量 \\
(桼) \\
\end{tabular} & $\begin{array}{c}\text { 脂 } \\
\text { 肪 } \\
\text { 量 } \\
(\%) \\
\end{array}$ \\
\hline \multirow{4}{*}{ 心 } & 1 & $\hat{o}$ & 175 & 176 & & 0.45 & 0.1036 & 0.0094 & 9.13 \\
\hline & 2 & $\hat{\delta}$ & 180 & 190 & & 0.49 & 0.1216 & 0.0133 & 10.92 \\
\hline & 3 & $\hat{o}$ & 180 & 186 & & 0.51 & 0.1233 & 0.0127 & 10.30 \\
\hline & 4 & $\hat{o}$ & 149 & 154 & & 0.42 & 0.1002 & 0.0085 & 8.49 \\
\hline \multirow{2}{*}{ 臟 } & 5 & $\hat{o}$ & 168 & 178 & & 0.47 & 0.1091 & 0.0108 & 9.90 \\
\hline & 平均 & & 170 & 177 & $(+4.1)$ & & & & 9.75 \\
\hline \multirow{6}{*}{ 肝 } & 1 & & & & & 6.17 & 2.0014 & 0.1738 & 8.68 \\
\hline & 2 & & & & & 5.75 & 1.9337 & 0.2752 & 14.22 \\
\hline & 3 & & & & & 6.30 & 2.0283 & 0.1573 & 7.75 \\
\hline & 5 & & & & & 4.38 & 1.2748 & 0.1329 & 10.42 \\
\hline & 5 & & & & & 4.42 & 1.3529 & 0.1327 & 9.83 \\
\hline & 平均 & & & & & & & & 16.18 \\
\hline \multirow{4}{*}{ 腎 } & 1 & & & & & 0.88 & $0.2279 \mid$ & 0.0262 & 11.51 \\
\hline & 2 & & & & & 0.86 & 0.2246 & 0.0286 & 12.70 \\
\hline & 3 & & & & & 1.00 & 0.2521 & 0.0276 & 10.95 \\
\hline & 4 & & & & & 0.75 & 0.1591 & 0.0168 & 10.56 \\
\hline \multirow{2}{*}{ 臟 } & 5 & & & & & 0.80 & 0.2120 & 0.0237 & 11.19 \\
\hline & 平均 & & & & & & & & 11.38 \\
\hline \multirow{6}{*}{$\begin{array}{l}\text { 骨 } \\
\text { 骼 } \\
\text { 筋 }\end{array}$} & 1 & & & & & 1.78 & 0.4760 & 0.0236 & 4.97 \\
\hline & 2 & & & & & 1.90 & 0.3145 & 0.0250 & 4.87 \\
\hline & 3 & & & & & 1.86 & 0.4782 & 0.0167 & 3.50 \\
\hline & 4 & & & & & 1.77 & 0.4400 & 0.0147 & 3.34 \\
\hline & 5 & & & & & 1.78 & 0.4692 & 0.0145 & 3.09 \\
\hline & 平均 & & & & & & & & 3.65 \\
\hline
\end{tabular}




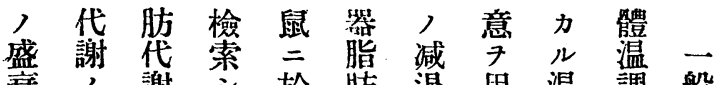
衰了謝主於肪退用温調般 二减 $八 テ$ 含 $ト$ 域節 對退䒕室實有共 $ッ$, 機生 シ 7 進 温 瞼 量 二、略 關體 抑牀二的㕣諸白々 等 新 著制態於外伯 臟 鼠攝 ス陳 シ ス テ テ 界加器二氏 キ ル ア 八氣 7 脂倠三テ 謝 影モル脂温招肪温士體人 響ノ 7 肪ノ來含 7 温最 尹、認新高七有作度了モ

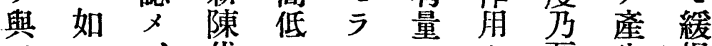
フク、代二ルノ七至生慢 ナ而適 謝寻

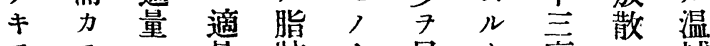
キモノ量肪ナ見ト度二域 確垶睪ノ新ルキ二關換 丸 丸 垶 陳 事高八ア ス 言 得剔粉丸代 7 温、 ルルス 夕出末粉 謝實 體モ 諸レ

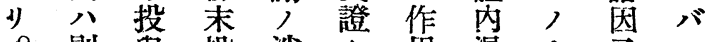
剔興投渻七角温ナ尒宓

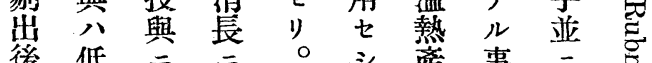

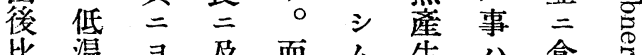

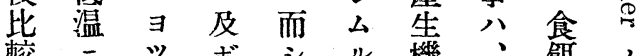
較 $ョ$ ボジ機第㣮, 短儿促辠 前於.轉第如譄 時脂進 丸章 テ 旺篇何臨 日肪七, 實八盛二等界 二新 ラ 影殮之於三温

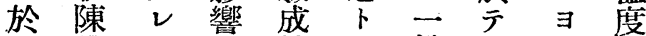
テ代、尹 績全般劷り少 八謝 又體三ク物述亏動 低, 去重示反質七異物

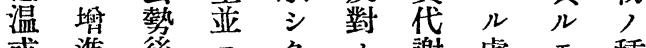
或進後三夕, 謝處モ種 八テ比諸ル機ノナノ類 高助較臟 ガ轉芹り二乃 温長的器如二進。至 三 、智脂 ク 几高日含予亏方予白二 脂温二有八體、少 肪二ア・量更重體臨二リ 新 $コ$ 二 二並重界於或 陳ルテッ雄二霄温テ分 代脂八未性諸加度 八. 習 謝肪脂 テ 白臟度 二 斯慣

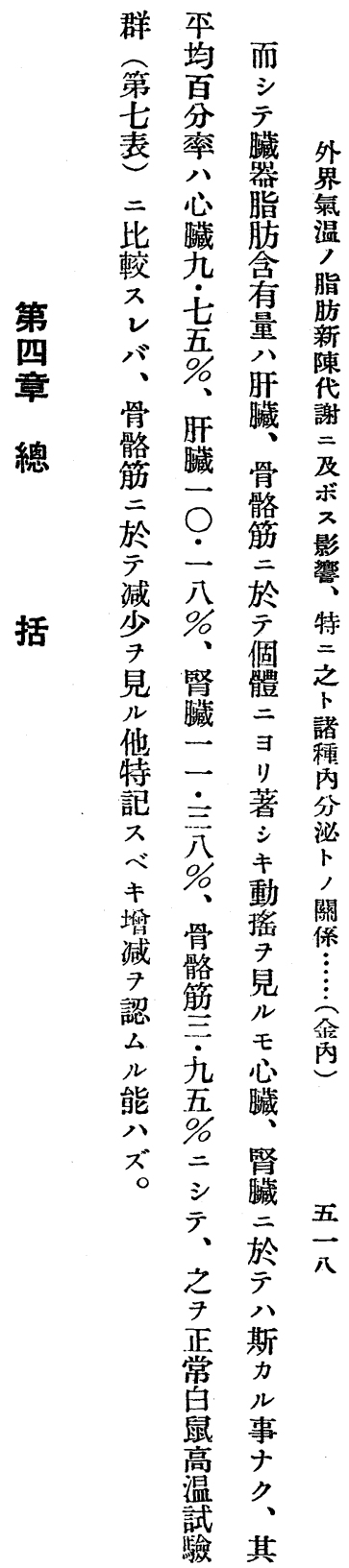

群 尔

第 百 シ

七分 テ

八器藏 外

二心 脂 氣

比 臟 肪 温

九含念脂

ス七有肪

バ吾量 新

骨 肝臟 謝

䈷 臟 骨 及

二 $\overrightarrow{0}$ 骼

テ - 朌 影

少 \% テ 特

7 、個 =

見腎 體 之

仙 䁍 三 諸

特一リ稿

訅兰著分

ベ キ キ

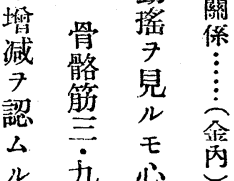

厹態歲

ス $\%$ 腎

シ 臟

文五

子 ハ

正 斯

白 ル

鼠 事

高 ナ

其 


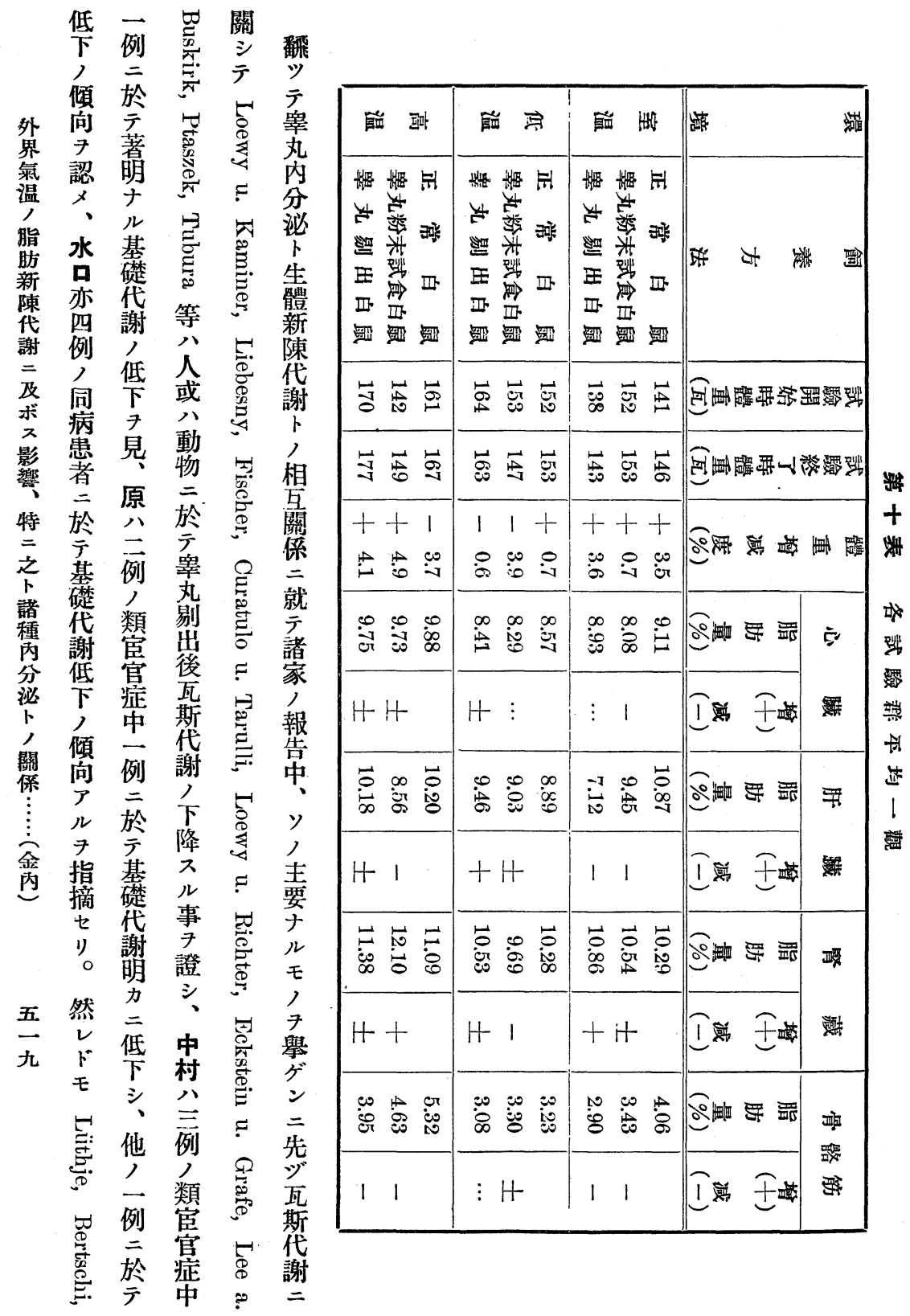




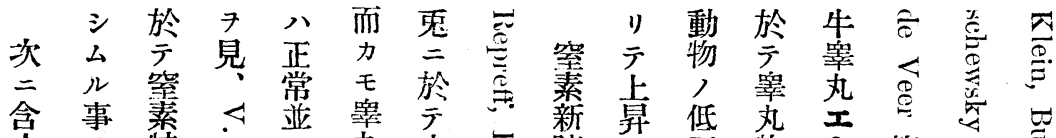

水

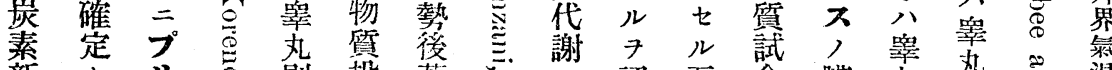

新七 リ

陳り 代

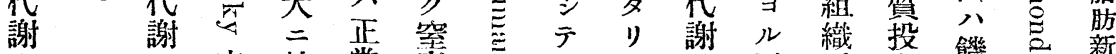

，低 栾 於 常 素

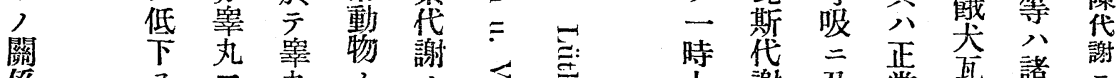

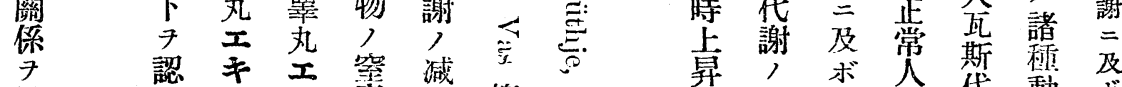

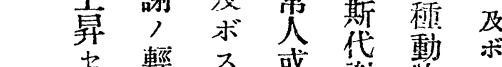

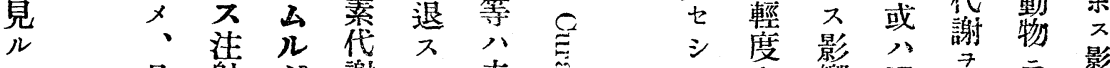

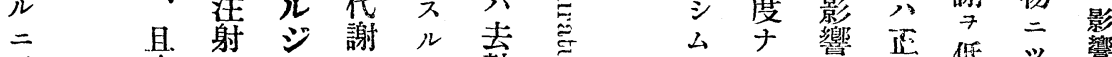

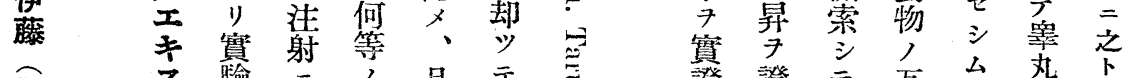

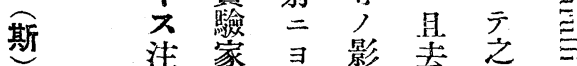

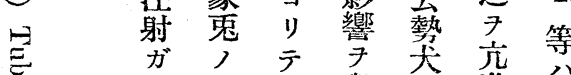

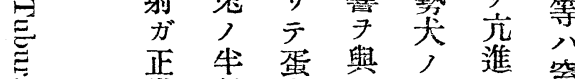

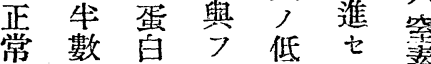

等 牡二代ル市 シ 系

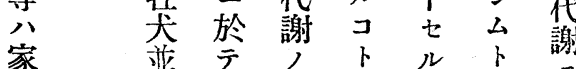

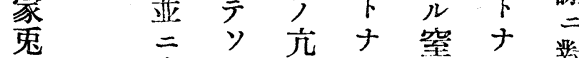

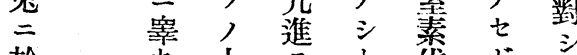

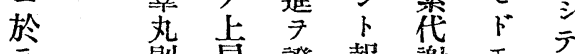

テ 剔昇證報謝 モ 去

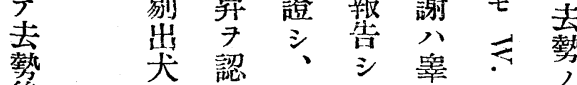

後, $x$ 然可丸 $=$ 影

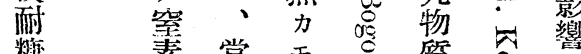

粮

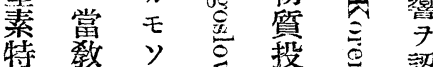

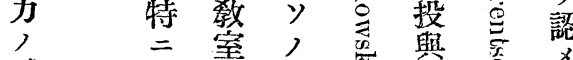

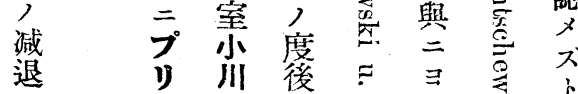

ス

ル

7

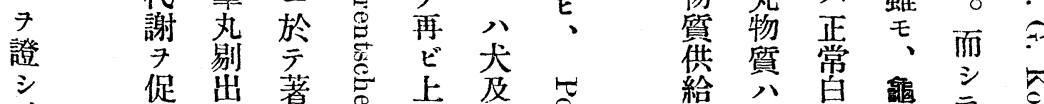

リ川後 リ

證證テ、瓦ル剔諸

シ得之斯事出種

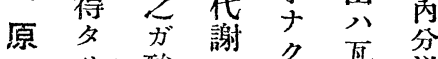

類り 酸 殆 却斯 泌

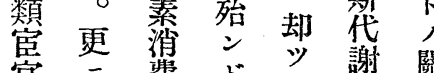

宦二費

蟔

者齐高毛等令

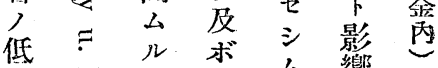

下 总 傾

七

瓦

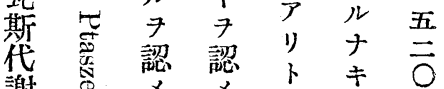

謝

睪 八篠多告見

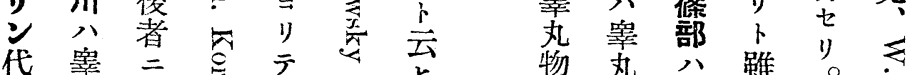

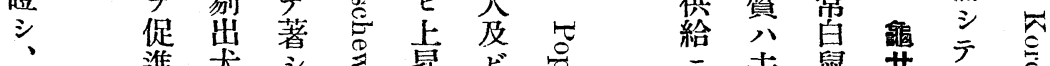

更進 犬 主 辛昇 ビ 


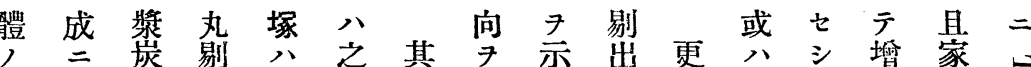

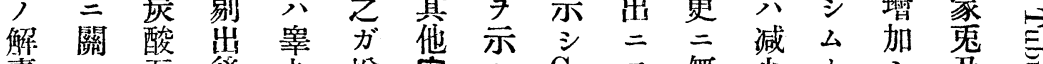

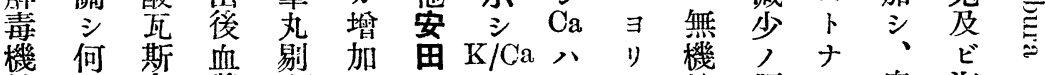

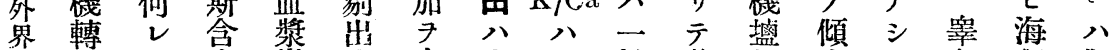

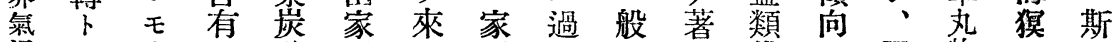
温 三 家量酸兔 $九$ 兔牛二三代、由物二力 脂テ兔公瓦二コニ數增ク謝睪中質於ル 肪了三睪斯於卜於三加之年公投页耐

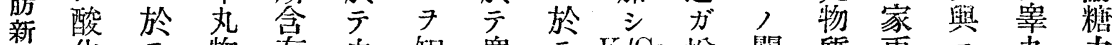

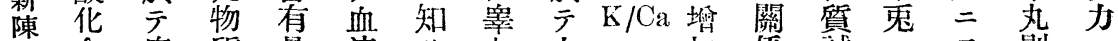
代合睪質量液り丸卡八加係試二ヨ剔八 謝成丸試公酸、 7 兵下 7 食於り出减 二機 剔食徐素睪剔 ス 降見就三テ 及轉出三々解丸出卜乃ル年其减妇八 栤 $=$ 後 $\exists$ 離物

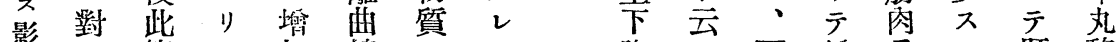
戀 シ 等

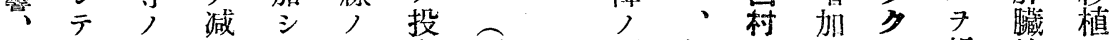
特有合少、下與剔傾伊八及下報糖二 二利成入血降八出向藤家八ア 告原

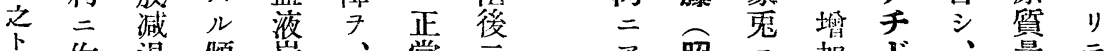

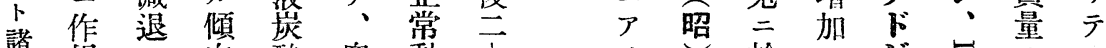

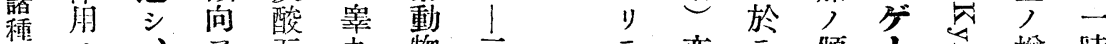

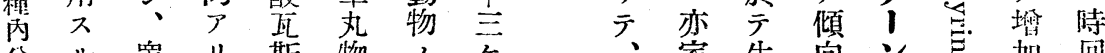

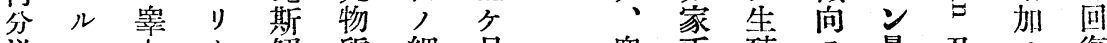

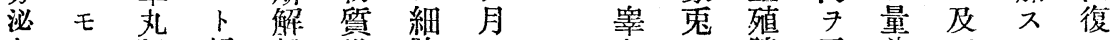
卜, 粉報離投胞二炛三腺示㫫ビルシ

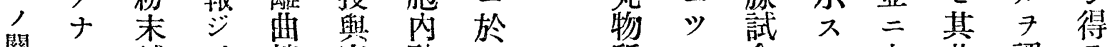
關亏試、線家酸亏質キ食 楅 食小八兔化 八 占結寻追泉於能 臟

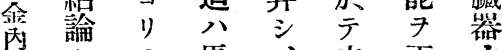

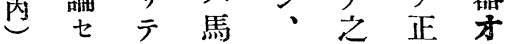
リ㙫尿更 ガ常 キ $\circ$ 加酸三上㘳 公威劣昇上多

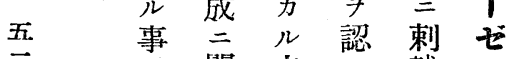
三 7 關去 、战 公 實 シ 勢、克减 證 新二國進少 宫依行七少 以イテ家公殬

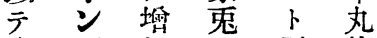
辠 ヂ 加 云 物 丸力 七 於 $七$ 質 生合血睪 飯 食 子辠三認中同 投杂 $\exists 邓 、$ 者、 與剔り夕旰采乎

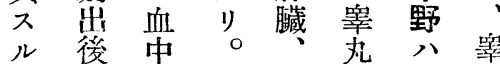
時 y カ 筋抽家扎 八, 几肉出兔物 血血于学物厓質 清 清ウ酸 ガ臟試 中 $\mathrm{K}$ 量 量 雄糖 食

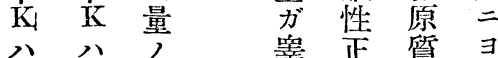
筜减减常量 加少少 剔家苾 シ乃＼cjkstart出兔等 $\mathrm{Ca}$ 至 傾二, 丸力 亦葴向血剔、 增少 $\exists$ 糖出儿 茄, 示劣

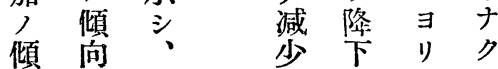


首 减 謝

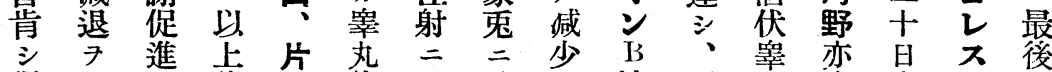

田 ガ 注 家 ノミ達 潛 河 得見七諸岡、物 $\exists$ 於 7 缺更 丸睪內 ラルラ家二質り ルモレノ $コ$ 試 テ 血制白正成剔二ン肪 界 、, 、報り食抑中鼠常後出於量新氣 處、反告 $テ 二$ 制脂ルニ云後テ, 陳温

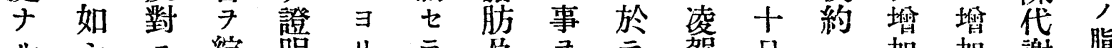

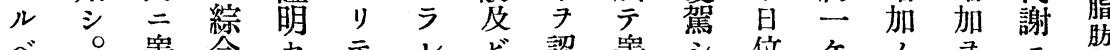

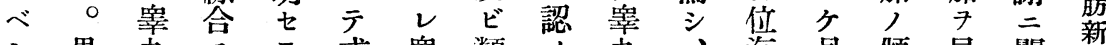

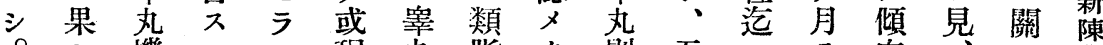

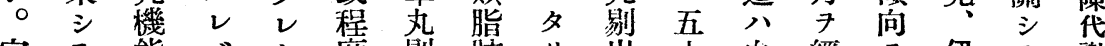
室示能バタ度 剔肪り出十血經年伊テ謝 温然䐋、儿汽出體。八日過示藤八 $=$

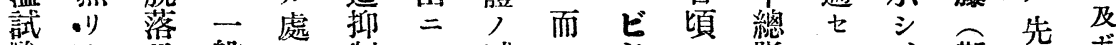

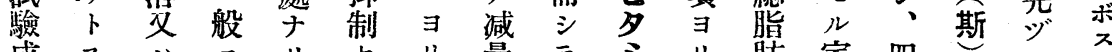
成ス八二リ七り量テ方少肪家四甚影

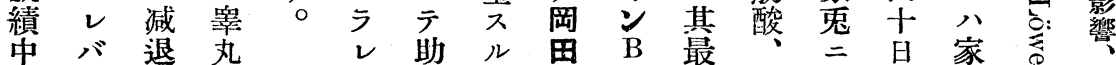
睪: $\vec{\jmath}$ 物、長 7 缺高七於前兔异特 丸予ル質 剔 ガ 時 投 出室 二 與 後 温 八二 比低逐 較温三リ

的高八

短 温 體 體

時試內 內

日噞 酸 酸 二 = 化 化 於 於機機 テ テ 轉 轉 白睪了旺 鼠 丸低盛 體 粉 下 r 重策、ナ 投 $\overrightarrow{\text { 投 }}$

加 三 新

大際陳 般 ナ シ 代 新 ラ 謝陳 ズ、得 從 代 且ルテr 藏 成 脂 共 器 績 肪 脂 分代 脂 肪 略 謝 肪 含郘代

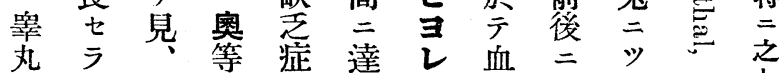
丸 ラ 久等 症 達 し 血二ツ"之

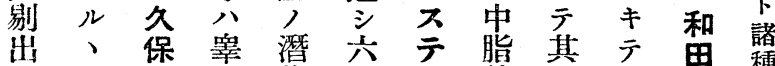

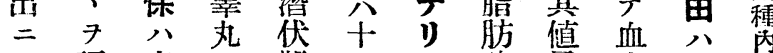
$\exists$ 認家工期日、並最中家分

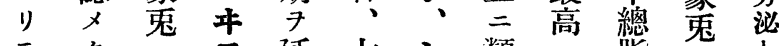
厂夕二ス延七し類二脂卡 助》於了長十于脂達肪於, 長

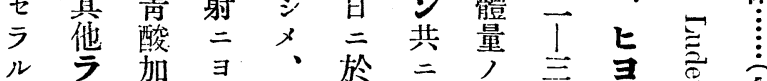

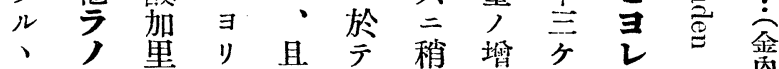

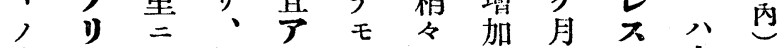

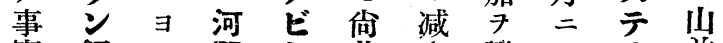
實飼儿野夕此少證シリ羊

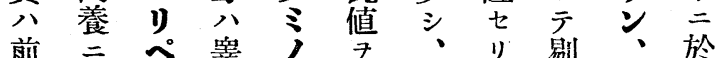
者 $\exists 、$ 持以。出 只主物セ續後水前手何三 小實ガ質三ス次口乎レ 出鐱、試 $コ$ 第八值ンモ 二的睪食ルチ二家二八睪 ヨ家丸二臓見增兔復兩丸 リ兔工 $エ$ 筑量三歸 側剔 、動 キリ脂大於入睪出 後脈 ス、肪村テ原热後 者硬, 何含八正萝 7 剔血 變䒚 $レ$ 有ビ常驗認出中

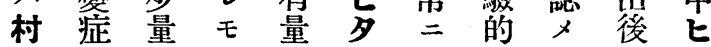




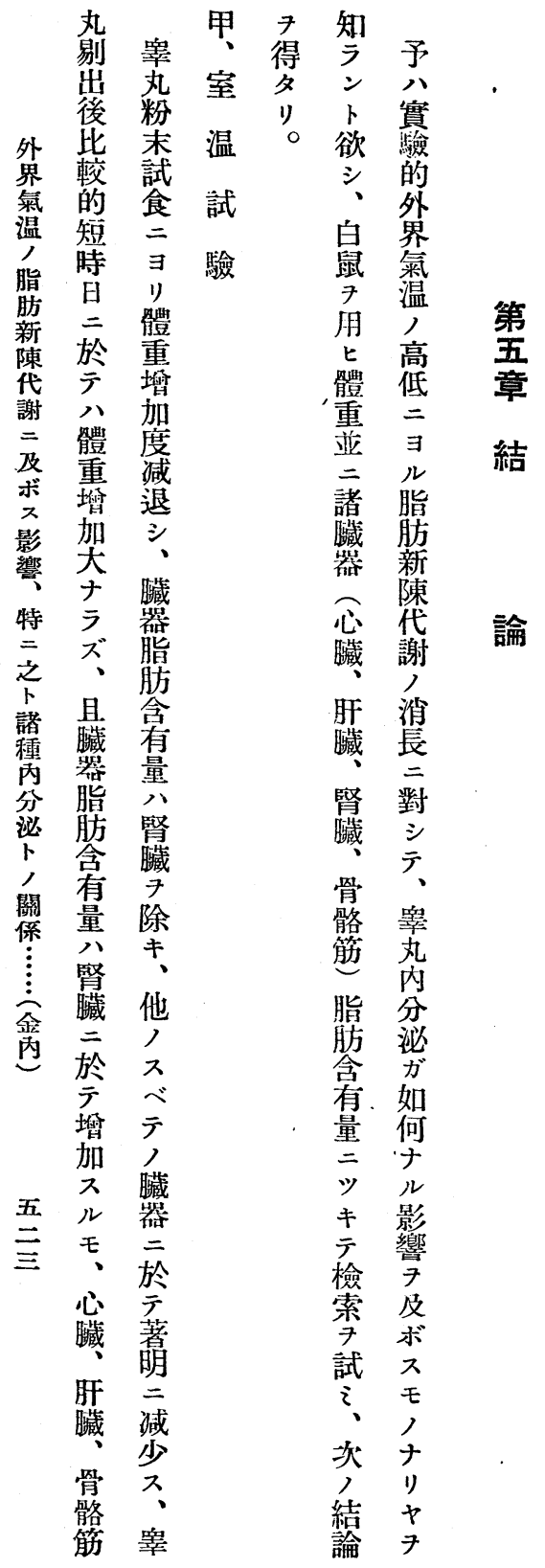

ラ

卜諸而而能代冬星

思種 シ力芹償减督

惟要 テ モ 進的少藏

ス約諸石

之試狀儿熋見除

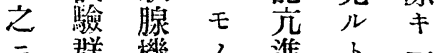

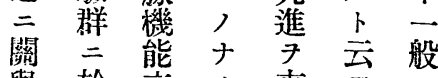

與於芹儿來亏

ス隻事 七 前减

ルルフ八述少

モ幵見當結水,

人臟 䙲 果 口狀

ナ肶力室 二, 態

ラ肪、要非報气

ン量一田儿音ア

モ>般ガカ展ル

檑新等、其八

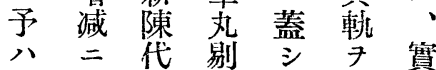

其八謝出睪 一 靈

際該艺白丸二的

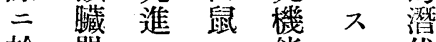

於器 三二能ル伏

々, 特於脫モ睪

新二亏落, 丸

肝陳脂水或 $卜$ 形

臟代肪口八考成

糖謝, ガ减 フ後

原二燃䁈退儿比

貿 關 燒 驗 後 7 較

量 $入$ 旺的比得的

ノル盛潛較 今゙短

如 機 卢伏的》時

何能ナ睪短、日

ガノル 丸時恐。二

甚特八形白亏

名二今成二ク

大密 日白ア睪テ

ナ葌餘鼠り扎八

儿且り二テ剔血

役泉二於甲出中

割 雜 $\overline{\bar{\gamma}}$ 狀 脂

$尹$ 多明確腺 $\exists$ 肪

演 岐瞭證艻り並

ズ

ル互軠時甲類

モ 事處代狀脂

ナ鑑實三償腺澧 


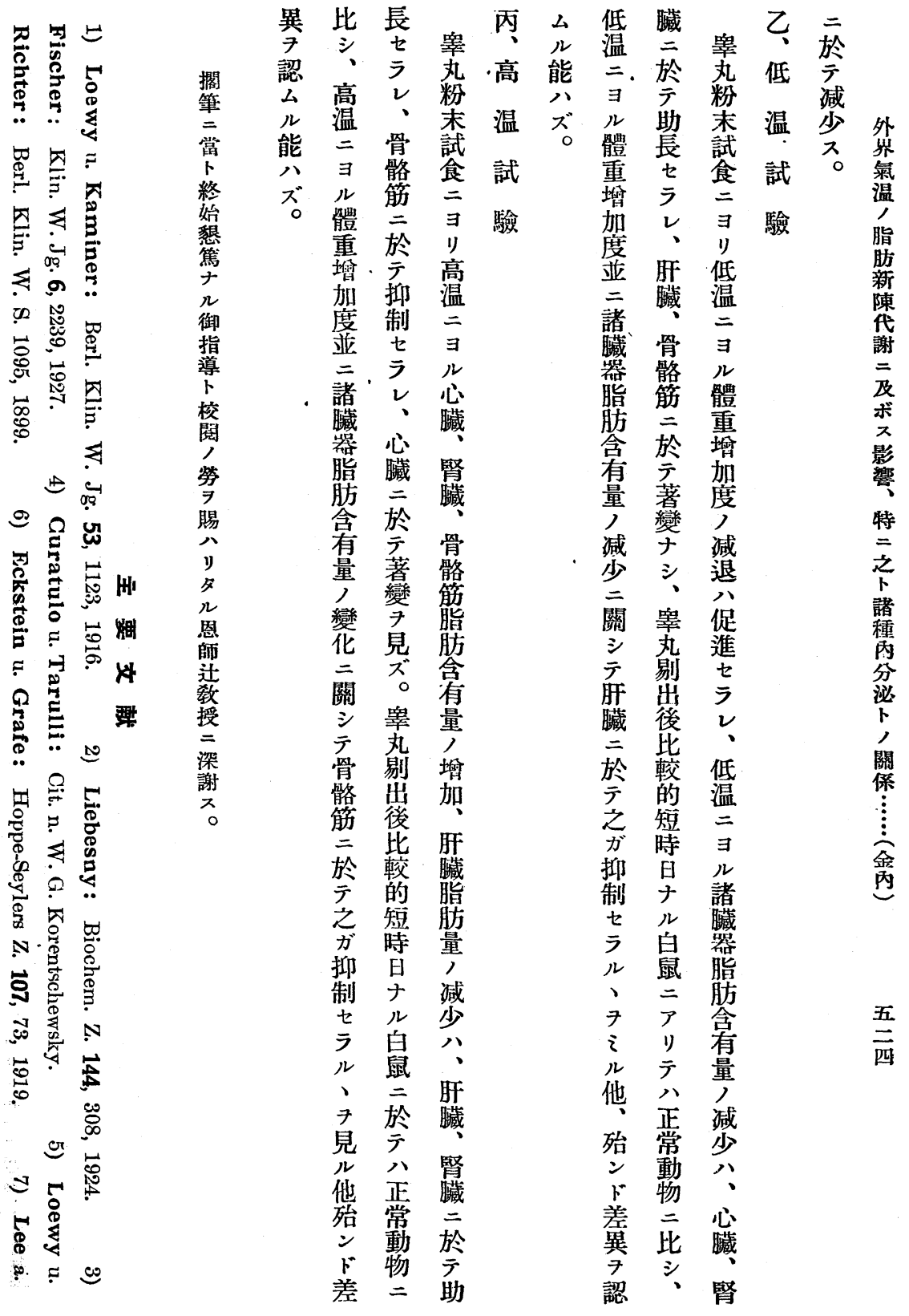




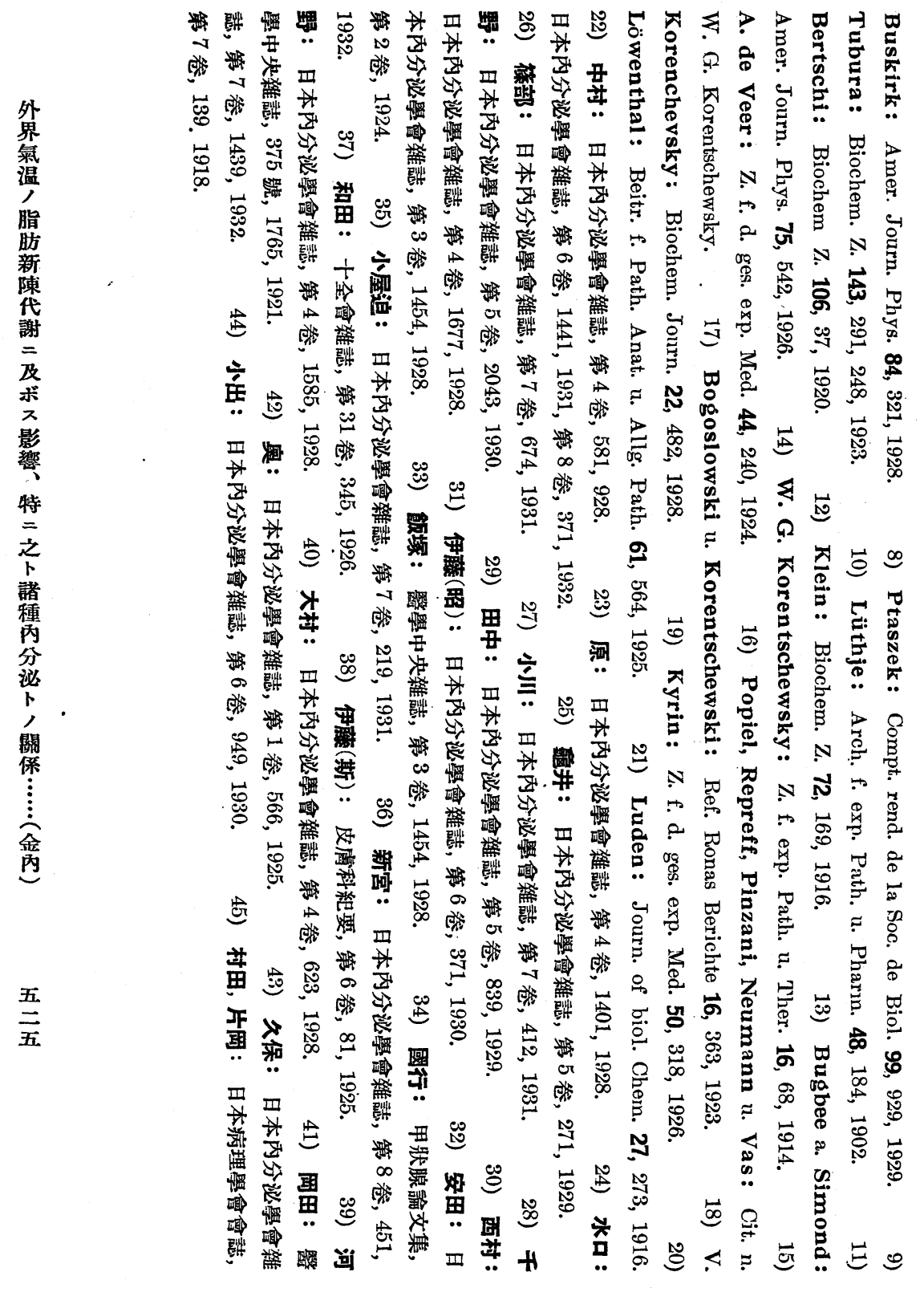


geteilt. Die vorliegende Mitteilung bringt Näheres über diese Substanzen in der Schleimhaut des Verdauungskanals. Die Untersuchungsmethode war wie die in der früheren Mitteilung angegebene.

Die Resultate waren wie folgt:

1) Der wässerige sowie der säurealkoholige Extrakt aus der Oesophagusschleimhaut des Hundes senken den Blutzuckerspiegel nicht, sondern wirkten mehr hyperglykämisch.

2) Der säurealkoholige Extrakt aus der Magenschleimhaut des Kaninchens oder des Hundes erzeugt leichte Hypoglykämie, w̦ährend der wässerige Extrakt unwirksam ist.

3) Der wässerige sowie der säurealkoholige Extrakt aus der Dünndarmschleimhaut des Kaninchens oder des Hundes wirken stark hypoglykämisch.

4) Der wässerige sowie der säurealkoholige Extrakt aus der Coecumschleimhaut des Hundes erzeugen hochgradige Hypoglykämie.

5). Was die Dickdarmschleimhaut des Kanischens oder des:Hundes anbetrifft, so wirkt nur der säurealkoholige Extrakt hypoglykämisch, der wässerige dagegen nicht.

6) Nicht nur Kaninchen und Hund, sondern auch verschiedene andere Warmblüter (Ochs, Ziege, Katze, Schwein, Huhn, Meerschweinchen, Pferde und Ratte) enthalten in der Darmschleimhant hypoglykämische Substanzen, nicht aber die Kaltblüter (Kröte, Elepha climacophora und Karpfen).

(Autoreferat)

\section{Über die Beziehung zwischen Aussentemperatur und Hoden in Bezug auf den Fettstoffwechsel.}

Von

Dr. S. Kanauchi.

(Aus der I. Med. Klinik der Kaiserl. Univers. zu Kyoto in Japan.

Direktor: Prof. Dr. K. Tsuji.)

Der Verfasser studierte den Fettgehalt einzelner Organe (Herz, 
Leber, Niere und Skelettmuskel) an normalen, kastrierten und mit Hodenpulver gefïtterten Ratten, die 7 Tage lang bei Zimmertempera$\operatorname{tur}\left(8^{\circ} .5-16^{\circ} \mathrm{C}\right.$. $)$ und erniedrigter $\left(2^{\circ}-5^{\circ} \mathrm{C}\right.$. $)$ oder erhöhter $\left(28^{\circ}-32^{\circ} \mathrm{C}\right.$. $)$ Aussentemperatur gehalten wurden.

Die Fettbestimmung wurde mittels des Soxhletschen Apparates nach der Aetherextraktionsmethode ausgeführt.

Die Resultate lassen sich kurz wie folgt zusammenfassen:

A. Bei Zimmertemperatur :

1) Bei mit Hodenpulver gefütterten und kastrierten Ratten (18 Tage nach der Operation getötet) nimmt der Fettgehalt von Herz, Leber und Skelettmuskel im Vergleich mit diesen Organen normaler Ratten stark ab, während er in der Niere dagegen Tendenz zur Zunahme zeigt.

B. Bei erniedrigter Aussentemperatur:

1) Bei mit Hodenpulver gefütterten Ratten nirnmt der Fettgehalt von Herz und Niere im Vergleich mit diesen Organen normaler Ratten ab, während der Fettgehalt der Leber und des Skelettmuskels fast unbeeinflusst bleibt.

2) Bei kastrierten Ratten nimmt der Fettgehalt in der Leber im Vergleich mit diesem Organ normaler Ratten zu, während der von Herz, Niere und Skelettmuskel fast unbeeinflusst bleibt.

C. Bei erhöhter Aussentemperatur :

1) Bei mit Hodenpulver gefütterten Ratten nimmt der Fettgehalt von Leber und Skelettmuskel im Vergleich mit diesen Organen normaler Ratten ab, während es in der Niere dagegen zu Vermehrung kommt.

2) Bei kastrierten Ratten nimmt der Fettgehalt des Skelettmuskels im Vergleich mit diesem Organ normaler Ratten ab, während der Fettgehalt von Herz, Leber und Niere fast unbeeinflusst bleibt.

(Autoreferat) 